\title{
Faktor-Faktor yang Mempengaruhi Hipotensi Intradialisis pada Pasien Gagal Ginjal Kronik yang Menjalani Hemodialisis
}

\author{
Zahrah Maulidia Septimar' ${ }^{1}$, Desi Retno Nurmalahayati² \\ Program S1 Keperawatan STIKes YATSI Tangerang \\ JI. Aria Santika No.40A, Margasari, Karawaci, Kota Tangerang, Banten 15114 \\ Email: pangeran_jojoy@yahoo.co.id ; desirnm@gmail.com
}

\begin{abstract}
Abstrak
Hemodialisis digunakan bagi klien dengan gagal ginjal akut atau gagal ginjal yang sudah tidak dapat diperbaiki serta ketidakseimbangan cairan dan elektrolit. Tujuan penelitian ini untuk menganalisis faktor-faktor yang mempengaruhi hipotensi intradialisis pada pasien Gagal Ginjal Kronik (GGK) yang menjalani hemodialisis. Jenis penelitian ini menggunakan analitik korelasi dengan pendekatan Cross Sectional. Populasi sebanyak 63 responden, dengan jumlah sampel sebanyak 18 repsonden. teknik pengambilan sampel dengan purposive sampling. Hasil penelitian ini diperoleh usia lansia (46-65 tahun) $5 \mathrm{I}$ responden $(81,0 \%)$, jenis kelamin perempuan 32 responden $(50,8 \%)$, yang tidak menggunakan obat antihipertensi 43 responden (68,3\%), yang mengalami anemia sedang 34 responden (54,0\%), pengukuran tekanan darah pre hemodialisa tidak mengalami hipotensi adalah 45 responden $(7 \mathrm{I}, 4 \%)$. Hasil penelitian menunjukkan sebanyak 18 responden $(28,6 \%)$ mengalami hipotensi intradialisis dan adanya pengaruh antara usia, obat antihipertensi dan anemia dengan kejadian hipotensi intradialisis, sedangkan tidak ada pengaruh antara jenis kelamin dengan kejadian hipotensi intradialisis. Untuk peneliti selanjutnya bisa melakukan penambahan sampel dan faktor resiko lain seperti faktor disfungsi otonom (diabetes mellitus dan uremia), makan selama hemodialisis, dan pengaruh berat badan sebelum dan sesudah tindakan hemodialisis.
\end{abstract}

Kata kunci : Gagal Ginjal Kronik (GGK), Hemodialisis, Tekanan Darah

\begin{abstract}
Hemodialysis is used for clients with Acute Renal Failure (ARF) and fluid and electrolyte imbalances. The purpose of this research to analyze the factors that effect intradialysis hypotension in patient with Chronic Renal Failure (CRF). Method Types of research used in this study using the type of analytic approach with cross sectional. Population of 63 patient, with a total sample of 18 respondents, sampling technique is the purposive sampling. The result of this research was age elderly (46-65 years) 51 respondent (8I,0\%). Most of the female gender 32 respondent $(50,8 \%)$, the some did not take as much antihypertensive medication 43 respondent (68,3\%), the respondent who had moderate anemia 34 respondent (54,0\%). The measurement of pre-hemodialysis blood pressure without hypotension intradialysis as much 45 respondent $(7 I, 4)$. The result showed that 18 respondent $(28,6 \%)$ patient experienced hypotension intradialysis and there is an influence between age, antihypertensive drugs and anemia with the incidence of intradialisis hypotension, whereas there is no influence between sex with the incidence of intradialisis hypotension. For future studies it is hoped that the research can further add research samples and addition of autonomic dysfunction factor (diabetic mellitus and uremia), food during hemodialysis, and weight influence before and after hemodialysis action.
\end{abstract}

Keywords : Chronic Renal Failure (CRF), Hemodialysis, Measure Blood Pressure 


\section{Pendahuluan}

Hemodialisis digunakan bagi klien dengan gagal ginjal akut atau gagal ginjal yang sudah tidak dapat diperbaiki serta ketidakseimbangan cairan dan elektrolit. ${ }^{1}$ WHO (World Health Organization) tahun 2015 memperkirakan ada sebanyak 36 juta orang di dunia meninggal akibat dari gagal ginjal kronik. Menurut United State Renal Data System tahun 2014 di Amerika Serikat prevalensi penyakit gagal ginjal kronik meningkat 20-25\% setiap tahun.

Di Indonesia angka kejadian gagal ginjal kronis menunjukkan peningkatan insiden penderita yang menjalani terapi hemodialisis dari tahun 2007-2012 yakni sebanyak 6862 orang pada tahun 2007, tahun 2008 sebanyak 7328 orang, tahun 2009 sebanyak 12.900 orang, tahun 2010 sebanyak 14.833 orang, 2011 sebanyak 22.304 orang dan 2012 sebanyak 28.782 orang. $^{2}$ Kasus gagal ginjal kronik di provinsi Banten sebesar 0,2\%. Di wilayah Tangerang pasien hemodialisis adalah 20\%-30\% bahkan biasanya mencapai $47 \%$. $^{3}$ Angka prevalensi ini didapatkan cukup tinggi pada pasien gagal ginjal kronik yang menjalani hemodialisis.

Terapi hemodialisis memiliki komplikasi yaitu hipotensi dan kram otot, komplikasi tersebut dapat memberikan stessor fisiologis dan psikologis kepada pasien. ${ }^{4}$ Hipotensi atau syok kardiovaskuler, juga mempengaruhi fungsi ginjal. Vasokontriksi ginjal menurunkan aliran darah ginjal. Memulihkan tekanan darah sistemik biasanya membalikkan vasokontriksi ginjal, dan fungsi ginjal kembali, khususnya dalam 2-8 minggu perawatan iskemia berkelanjutan tidak terjadi. Hipotensi intradialisis adalah penurunan tekanan darah dari sistolik $>30 \%$ dan tekanan diastolik sampai dibawah $60 \mathrm{mmHg}$ yang terjadi pada saat pasien menjalani hemodialysis. ${ }^{5}$

Menurut penelitian yang dilakukan Handayani, Ismonah, di RS Telogorejo Semarang tentang analisis faktor yang mempengaruhi hipotensi intradialisis pada pasien gagal ginjal kronik yang menjalani hemodialisis menyatakan sebanyak 23 (46\%) pasien mengalami hipotensi intradialisis $^{6}$. Penelitian yang dilakukan Roni, Ferdi di RSUD Dr. Ibnu Sutowo Baturaja sebanyak 40 orang yang mengalami peningkatan dan penurunan tekanan darah saat menjalani tindakan hemodialisis ${ }^{7}$. Oleh sebab itu, peneliti tertarik untuk melakukan penelitian lebih lanjut mengenai analisis faktor-faktor yang mempengaruhi hipotensi intradialisispada pasien gagal ginjal kronik yang menjalani hemodialisa di RSU Kabupaten Tangerang.

\section{Metode Penelitian}

Penelitian ini menggunakan pendekatan Cross Sectional dengan jumlah populasi penelitian 60 responden, dengan jumlah sampel 18 responden. Metode yang digunakan ini purposive sampling yaitu metode pemilihan sampel yang dilkukan berdasarkan maksud dan tujuan tertentu yang ditentuakn peneliti ${ }^{8}$. Dengan kriteria inklusi : pasien yang menjalani hemodialisa, pasien tekana darahnya $<90$ $\mathrm{mmHg}$, pasien dengan diagonosa Penyakit Ginjal Kronik. Instrumen penelitian yang digunakan dalam pengumpulan data penelitian yaitu spignomanometer dan stetoskop dan buku untuk mencatat hasil observasi, selanjutnya dilakukan uji statistik dengan metode Chi square $\left(x^{2}\right)$.

\section{Hasil Penelitian}

Tabel 1. Analisa Univariat

\begin{tabular}{llcc}
\hline \multicolumn{1}{c}{ Variabel } & \multicolumn{1}{c}{ Kategori } & n & \% \\
\hline Usia & Remaja (12-25 & 0 & 0 \\
& th) & & \\
& Dewasa (26-45th) & 12 & 19 \\
& Lansia (46-65th) & 51 & 81 \\
Jenis Kelamin & Laki-laki & 31 & 49,2 \\
& Perempuan & 32 & 50,8 \\
Obat & Tidak & 43 & 68,3 \\
Antihipertensi & Ya & 20 & 31,7 \\
Anemia & Ringan & 5 & 7,9 \\
& Sedang & 34 & 54,0 \\
Tekanan Darah & Berat & 24 & 38,1 \\
Pre Hemodialisa & $<20 \mathrm{mmHg}$ & 45 & 71,4 \\
& $\geq 20 \mathrm{mmHg}$ & 18 & 28,6 \\
\hline
\end{tabular}

Berdasarkan tabel 1 diketahui bahwa dari hasil penelitian karakteristik usia 
Tabe1 2. Analisa Bivariat

\begin{tabular}{|c|c|c|c|c|c|c|}
\hline \multirow{3}{*}{ Variabel } & \multirow{3}{*}{ Kategori } & \multicolumn{4}{|c|}{ Tekanan Darah } & \multirow{3}{*}{$\mathbf{P v}$} \\
\hline & & \multicolumn{2}{|c|}{$<20 \mathrm{mmHg}$ (Tidak Hipotensi) } & \multicolumn{2}{|c|}{$\begin{array}{l}\geq 20 \mathrm{mmHg} \\
\text { (Hipotensi) }\end{array}$} & \\
\hline & & $\mathbf{n}$ & $\%$ & $\mathbf{n}$ & $\%$ & \\
\hline \multirow[t]{3}{*}{ Usia } & Remaja (12-25 th) & 0 & 0 & 0 & 0 & 0,013 \\
\hline & Dewasa (26-45th) & 12 & 19,0 & 0 & 0 & \\
\hline & Lansia (46-65th) & 33 & 52,4 & 18 & 28,6 & \\
\hline \multirow{2}{*}{ Jenis kelamin } & Laki-laki & 23 & 36,5 & 8 & 12,7 & 0,782 \\
\hline & Perempuan & 22 & 34,9 & 10 & 15,9 & \\
\hline Obat & Tidak & 35 & 55,6 & 8 & 12,7 & 0,016 \\
\hline Antihipertensi & $\mathrm{Ya}$ & 10 & 15,9 & 10 & 15,9 & \\
\hline \multirow[t]{3}{*}{ Anemia } & Ringan & 5 & 7,9 & 0 & 0 & 0,000 \\
\hline & Sedang & 34 & 54,0 & 0 & 0 & \\
\hline & Berat & 6 & 9,5 & 18 & 28,6 & \\
\hline
\end{tabular}

responden yang terbanyak adalah lansia (46-65 tahun) sebanyak 51 responden, jenis kelamin responden yang terbanyak adalah perempuan sebanyak 32 responden, karakteristik obat antihipertensi, dimana ada 43 responden yang tidak menggunakan obat antihipertensi. Karakteristik anemia, responden yang terbanyak adalah 34 responden yang mengalami anemia sedang. Tekanan darah responden yang terbanyak adalah pasien tidak hiptebsi sebanyak 45 responden.

Berdasarkan hasil uji chi square pada tabel 2 dapat dinyatakan secara statistic bahwa terdapat pengaruh antara usia dengan kejadian hipotensi intradialisis pada pasien yang menjalani hemodialisis $(\mathrm{Pv}=0,013)$. Begitu juga dengan variabel obat antihipertensi dan status anemia dimana masing-masing nilai uji bivariate adalah $\mathrm{Pv}=0,016$ dan $\mathrm{Pv}=0,000$. Sedangkan untuk variabel jenis kelamin tidak berhubungan dengan kejadian hipotensi intradialisis pada pasien yang menjalani hemodialisis $(\mathrm{Pv}=0,782)$.

\section{Pembahasan}

Berdasarkan hasil penelitian yang dilakukan di RSU Kabupaten Tangerang Tahun 2018 dapat disimpulkan bahwa karakteristik usia responden yang terbanyak adalah lansia (46-65 tahun) sebanyak 51 responden. Dan ada pengaruh antara usia dengan kejadian hipotensi intradialisis pada pasien yang menjalani hemodialisis.
Hasil penelitian ini diperkuat dengan penelitian yang dilakukan Handayani, Ismonah, dengan judul analisis faktor yang mempengaruhi hipotensi intradialisis pada pasien gagal ginjal kronik yang menjalani hemodialisis ${ }^{9}$, dari hasil penelitian yang dilakukan dengan jumlah 50 responden didapatkan sebagian besar responden berusia 56-65 tahun sebanyak 24 responden $(48 \%)^{10}$.

Berdasarkan hasil penelitian yang dilakukan di RSU Kabupaten Tangerang Tahun 2018 dapat disimpulkan bahwa karakteristik jenis kelamin responden yang terbanyak adalah perempuan sebanyak 32 orang $(50,8 \%)$, sedangkan laki-laki sebanyak 31 orang $(49,2 \%)$.

Berdasarkan uji chi square bawa $p=$ value $0.78>0.05$ maka dinyatakan Ho diterima artiinya tidak ada pengaruh antara jenis kelamin dengan kejadian hipotensi intradialisis pada pasien yang menjalani hemodialisis.

Hasil penelitian ini diperkuat dengan penelitian yang dilakukan Handayani, Ismonah, dengan judul analisis faktor yang mempengaruhi hipotensi intradialisis pada pasien gagal ginjal kronik yang menjalani hemodialisis, dari hasil penelitian yang dilakukan dengan jumlah 50 responden didapatkan responden yang tidak mengalami hipotensi intradialisis yang berjenis kelamin laki-laki 34 responden (68\%) dan perempuan 16 responden $(32 \%)$. 
Jenis kelamin tidak berpengaruh terhadap hipotensi intradialisis karena pada dasarnya pasien bukan baru pertama menjalani hemodialisis dikarenakan pada dasarnya pasien bukan baru pertama menjalani hemodialisis sehingga tingkat kecemasan pasien lebih ringan (sudah dalam fase penerimaan). Tekanan darah predialisis yang lebih rendah mengakibatkan terganggunya pengisian diastolik ventrikel kiri sehingga mengakibatkan hipotensi intradialisis saat hemodialisis $^{11}$

Berdasarkan hasil penelitian yang dilakukan di RSU Kabupaten Tangerang Tahun 2018 dapat disimpulkan bahwa karakteristik penggunaan obat antihipertensi responden yang terbanyak adalah tidak menggunakan obat antihipertensi sebanyak 43 responden $(68,3 \%)$, sedangkan yang menggunakan obat antihipertensi berjumlah 20 responden $(31,7 \%)$. Berdasarkan uji chi square bawa $p=$ value $0.016<0.05$ maka dinyatakan Ho ditolak artiinya ada pengaruh antara obat anti hipertensi dengan kejadian hipotensi intradialisis pada pasien yang menjalani hemodialisis.

Penelitian ini sesuai dengan penelitian yang dilakukan oleh Nur, Heedy, Widdhi (2013-2014) dengan judul studi penggunaan obat antihipertensi pada pasien gagal ginjal kronik yang menjalani perawatan di RSUP Prof. Dr. R. D. Kandou Manado periode Juli 2013 - Juni 2014. Didapatkan hasil jumlah responden yang menggunakan obat antihipertensi sebanyak 14 responden $(26,42 \%)^{12}$. Penggunaan obat antihipertensi pada pasien yang memerlukan obat-obatan (preparat glikosida jantung, antibiotik, antiaritmia, antihipertensi) harus dipantau dengan ketat karena penggunaan obat pada pasien dialisis dapat mencetuskan terjadinya hipotensi selama dialisis.

Berdasarkan hasil penelitian yang dilakukan di RSU Kabupaten Tangerang Tahun 2018 dapat disimpulkan bahwa karakteristik anemia ringan responden adalah sebanyak 5 responden $(7,9 \%)$, anemia sedang sebanyak 34 responden $(54,0 \%)$ sedangkan yang anemia berat berjumlah 24 responden $(38,1 \%)$. Berdasarkan uji chi square bawa $p=v a l u e$ $0.000<0.05$ maka dinyatakan Ho ditolak artiinya ada pengaruh antara anemia dengan kejadian hipotensi intradialisis pada pasien yang menjalani hemodialisis.

Penelitian Rahmat, Saiful, Dian dengan sampel 67 responden prevalensi anemia pada pasien gagal ginjal kronik adalah sebanyak 66 orang $(98,5 \%)$ sedangkan pasien gagal ginjal kronik yang tidak menderita anemia sebanyak 1 orang $(1,5 \%)$. Kadar hemoglobin terendah adalah sebesar 3,4 g/dl dan tertinggi sebesar $12,3 \mathrm{~g} / \mathrm{dl}^{13}$.

Berdasarkan hasil penelitian yang dilakukan di RSU Kabupaten Tangerang Tahun 2018 dapat disimpulkan bahwa karakteristik tekanan darah pre hemodialisa yang tidak mengalami hipotensi adalah sebanyak 45 responden $(71,4 \%)$, sedangkan tekanan darah pre hemodialisa yang mengalami hipotensi berjumlah 18 responden $(28,6 \%)$. Berdasarkan uji chi square bawa $p=$ value $0.016<0.05$ maka dinyatakan Ho ditolak artiinya ada pengaruh antara obat anti hipertensi dengan kejadian hipotensi intradialisis pada pasien yang menjalani hemodialisis.

Menurut Ommy Agustriadi, Ketut Suwitra, Gede Raka Widiana, Wayan Sudhana, didapatkan adanya perubahan volume darah relatif intradialitik yaitu penurunan volume darah relatif intradialitik antara 4,9\% sampai $26,4 \%$. Rerata penurunan volume darah relatif pada sampel yang mengalami episode hipotensi intradialitik adalah sebesar 7,2$12,9 \%$ dan yang tanpa episode hipotensi intradialitik sebesar $0,3-6,6 \%{ }^{14}$.

\section{Kesimpulan}

Berdasarkan hasil penelitian dimana terdapat penurunan tekanan darah pada pasien yang sedang mnjalani hemodialisa terdapat beberapa faktor yang mempengaruhi diantaranya usia, tekanan 
darah, obat anti hipertensi, anemia, sedangkan jenis kelamin tidak mempengaruhi penurunan tekanan darah selama hemodialisa.

\section{Saran}

Untuk peneliti selanjutnya, diharapkan bisa melakukan penambahan sampel penelitian dan penambahan faktor resiko lain mengenai hipotensi intradialisis seperti penambahan faktor disfungsi otonom (diabetes mellitus dan uremia), makan selama hemodialisis, dan pengaruh berat badan sebelum dan sesudah tindakan hemodialisis. Dan saran untuk pasien, diharapkan memperbaiki pola hidup dan evaluasi penggunaan obat anti hipertensi pada pasien gagal ginjal yang mnjalani hemodialisa.

\section{Daftar Pustaka}

1. Joyce M. Black and Jane Hokanson Hawks, Keperawatan Medikal Bedah Edisi Edisi 8 Buku 2 Bahasa Indonesia. Jakarta : Pentasada Media Edukasi; 2014.

2. Arief T, Zulfachmi W, Ibnu \& Fajar E. Analisis Faktor-Faktor yang Berhubungan dengan Kejadian Gagal Ginjal Kronik Pada Pasien Hemodialisis Di RSUD Tugurejo Semarang periode Januari-Desember 2014 ;2014.

3. Rahmat H, Syaiful A, \& Dian P. Hubungan Kejadian Anemia dengan Penyakit Ginjal Kronik pada Pasien yang Dirawat di Bagian Ilmu Penyakit Dalam RSUP Dr. M Djamil Padang Tahun $2010 ; 2010$

4. Yuni A. Hipotensi dan Hipertensi Intradialisis pada Pasien Chonic Kidney Disease (CKD) Saat Menjalani Hemodialisis Di RS PKU Muhammadiyah Yogyakarta ;2012

5. Restu P \& Woro S. Faktor Risiko Gagal Ginjal Kronik di Unit Hemodialisis RSUD Wates Kulon Progo ;2014.

6. Irma M \& Erika D. Faktor- Faktor Yang Mempengaruhi Nilai Interdialytic Weight Gain Pasien Hemodialisis Di RSUD Panembahan Senopati Bantul ;2017.

7. Roni F. Perubahan Tekanan Darah Pada Pasien Gagal Ginjal Kronis Sebelum dan Sesudah Menjalani Tindakan Hemodialisa di RSUD. Dr. Ibnu Sutowo Baturaja; 2015.

8. Kusuma KD. Metodologi Penelitian Keperawatan (Pedoman Melaksanakan dan Menerapkan Hasil Penelitian). Jakarta : CV. Trans Info Media ; 2011.
9. Handayani, Ismonah, dan Hendrajaya, Analisis Faktor Yang Mempengaruhi Hipotensi Intradialisis Pada Pasien Gagal Ginjal Kronik Yang Menjalani Hemodialisis di RS Telogorejo Semarang; 2013.

10. Ibnu F, Zulfahmi W dan Arief T. Analisis Faktor-Faktor Yang Berhubungan Dengan Kejadian Gagal Ginjal Kronik Pada Pasien Hemodialisis di RSUD Telogorejo Semarang; 2016.

11. Kasron \& Susilawati. Pengaruh Lama Menjalani Hemodialisis dengan Kejadian Intradialytic Hypertension (IDH) pada Pasien Chronic Kidney Disease (CKD) di RS Islam Fatimah Cilacap; 2017.

12. Nur, Heedy, dan Widdhi. Penggunaan Obat Antihipertensi Pada Pasien Gagal Ginjal Kronik Yang Menjalani Perawatan di RSUP Prof. Dr. R. D. Kandou Manado periode Juli 2013 - Juni 2014; 2014.

13. Reny M. Faktor-Faktor Yang Berhubungan Dengan Hipotensi Intradialisis Pada Pasien Gagal Ginjal Kronik Yang Menjalani Hemodialisis; 2014.

14. Agustriyadi O, dkk. Hubungan Antara Perubahan Volume Darah Relatif Dengan Episode Hipotensi Intradialitik Selama Hemodialisis Pada Gagal Ginjal Kronik di RSUP Sanglah Denpasar; 2009. 